\title{
Sistem Keamanan Rumah Yang Dapat Dikendalikan Melalui Android
}

\author{
Elang Abdul Azis ${ }^{1}$, Rahmat Hidayat ${ }^{2}$, Yulindon ${ }^{3}$ \\ ${ }^{1}$ Elangabdulaziz99@gmail.com, 2,Rahmat@pnp.ac.id, , ${ }^{3}$ Yulindon@pnp.ac.id \\ ${ }^{1}$ Mahasiswa, Politeknik Negeri Padang,
}

\begin{abstract}
The number of theft and increased crime makes many people afraid to leave the house because of the many crimes, therefore I aim to solve the problem in this case by creating a home control tool that can be controlled via Android. So people do not need to be afraid to leave the house because it can be controlled through Even great distances, of course this is very helpful in the problem of crime and can reduce crime rates

Banyaknya pencurian dan meningkatnya kriminalitas membuat banyak orang takut meninggalkan rumah dikarenakan banyaknya kejahatan oleh karena itu saya bertujuan melakukan pemecahan masalah dalam hal ini dengan menciptakan alat pengendalian rumah yang dapat di kendalikan melalui Android.Jadi orang pun tidak perlu takut meninggalkan rumah karena sudah bisa dikendalikan melalui jarak yang sangat jauhpun, tentu nya ini sangat membantu dalam masalah kejahatan dan dapat mengurangi angka kriminalitas
\end{abstract}

Kata kunci : pengedalian

\section{Pendahuluan}

Pada era globalisasi seperti saat ini perkembangan teknologi sangat pesat, teknologi yang terjadi pada alat yang tadinya manual kini menjadi serba otomatis dengan adanya mikrokontroler, hal ini dapat dilihat dari banyaknya peralatan elektronik dalam kehidupan sehari-hari yang serba otomatis, mulai dari pengaplikasian yang sederhana maupun yang lebih canggih.[1] Orang tidaklah mampu mengawasi semua area lokasi dari kantor, sehingga diperlukan sebuah sistem yang dapat memonitor setiap titik-titik dari area lokasi kantor menggunakan kamera terintegrasi dengan sistem visualisasi pada ruang petugas keamanan.[2] Hal diatas sangat mendasar untuk diperlukanya sistem kamera monitoring di ruangan yang ada diperusahaan tersebut dilihat dalam kondisi Real Time, Remote Acces, Saving, dan Surveillen.[3]

\section{STUDI ELEMEN PENDUKUNG}

A. PERANGKAT KERAS

Perangkat Keras yang digunakan dalam membuat alat keamanan pintu brankas ini dapat dilihat pada Tabel 1.[1]

Table 1. Perangkat Keras Alat Keamanan Pintu Brankas

\begin{tabular}{lll}
\hline No & Alat/bahan & Spesifikasi \\
\hline 1 & Mikrokontroler & AVR Atmega 16 \\
2 & Tombol input & Digital Switch \\
3 & Tombol reset & Digital Switch \\
4 & Lcd & Lcd $16^{*} 2$ black green \\
5 & Sensor finger print & Finger print \\
6 & Keypad & Keypad 4x4 \\
7 & Kunci & Kunci elektrik \\
8 & Chip komunikasi serial & Ic maxim 232 \\
9 & Resistor & Resistor karbon $1 / 4$ watt \\
10 & Kapasitor & Elco \\
11 & Transformator & Transformator 1a ct \\
12 & Kabel & Habel halus \\
13 & Stecker & Standar \\
14 & Konektor ke PC & Konektor DB9 \\
15 & Led & Led 3mm \\
16 & Saklar power & Seklar on off \\
17 & Solder & Solder 40w 220 v \\
18 & Timah & Timah potong dan runcing \\
19 & Obeng & Obeng plus dan min \\
20 & Cubing kabel & Pembungkus kabel 1mm \\
21 & Pcb system minimum & Pcb system minimum atmega16 \\
22 & Box & Aklirik 2mm \\
23 & Baut dan mur & Secukupnya \\
& & \\
\hline
\end{tabular}




\section{1) Finger print}

Sidik jari (fingerprint) atau Dactyloscopy adalah ilmu yang mempelajari sidik jari untuk keperluan pengenalan kembali identitas orang dengan cara mengamati garis yang terdapat pada guratan garis jari tangan dan telapak kaki.[4]. .Peningkatan motivasi kerja dan kinerja merupakan tantangan baru bagi dunia pendidikan dalam mengembangkan sumber daya manusianya.[5]

Perangkat fingerprint terdiri dari: powerbank untuk sumber energi, sensor fingerprint untuk pengambil sidik jari, LCD untuk menampilkan aplikasi absensi, keyboard untuk proses input data dan raspberry pi untuk kontrol sistem.[6]

Tujuan penggunaan finger print :

Menigkatkan keamanan pada pintu agar terdeteksi siapa yang masuk .

Lebih fleksibel dalam penggunan

Saat efisien dan tidak perlu lagi membawa kunci[7]

Kekurangan dari finger print :

Jika jari kita basah dia tidak dapat membaca pola jari kita .

Memerlukan baterai , karna itu mungkin saja ada sewaktu-waktu akan habis [8]

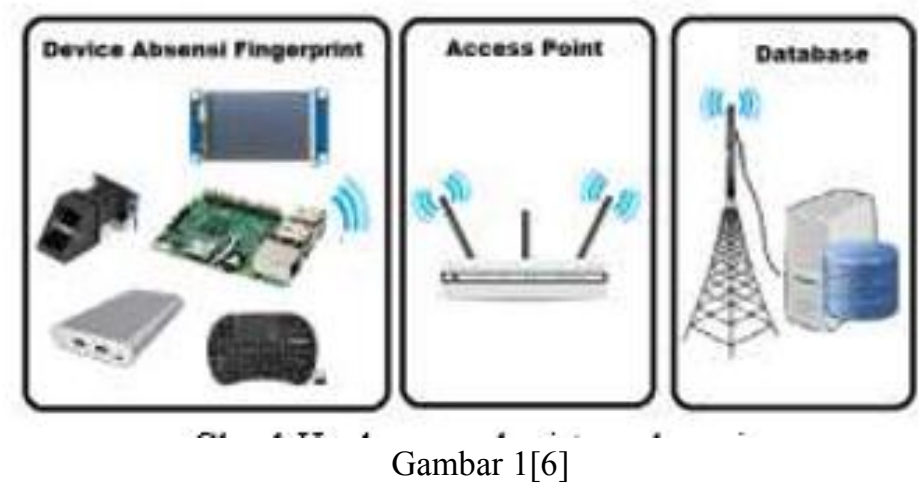

Desain sistem absensi mahasiswa terlihat pada gambar 1. Perangkat absensi dikoneksi dengan jaringan wifi lokal untuk mendapat mengakses database yang berada di server lokal. Selanjutnya dilakukan proses enroll untuk mendapatkan template sidik jari tiap user. Tamplate disimpan pada storage yang disediakan fingerprint scanner.[6]

\section{2) Perangkat Lunak}

Penelitian ini menggunakan software yaitu sistem operasi Linux Ubuntu 14.04 Lts. serta memakai tanpa harus membeli lesensi. Pada sistem operasi tersebut diinstall software yang ditunjukkan pada tabel 2.[9]

Table 2.software yang digunakan

\begin{tabular}{ll}
\hline Operating system & Linux Ubuntu 14.04 Lts \\
\hline DataBase & Mysql server \\
Web server & Apache2,PHP5 \\
Service & SSH,SSL,ICMP,Encfs \\
Software Cloud Storage & Pydio 8.0 Communty \\
Web panel & Ajenti
\end{tabular}

\section{3) Android}

Merupakan sistem operasi yang dikembangkan untuk perangkat mobile berbasis Linux. Pada awalnya sistem operasi ini dikembangkan oleh Android Inc, yang kemudian dibeli oleh Google pada tahun 2005.[10]

Fitur dan Arsitektur Android Fitur yang tersedia pada Android sebagai berikut :

1.Framework aplikasi : memungkinkan penggunaan dan pemindahan dari komponen yang tersedia.

2. Dalvik Virtual Machine : virtual machine yang dioptimalkan untuk perangkat mobile.

3. Grafik : grafik 2D dan grafik 3D yang didasarkan pada library OpenGL.

4. Mendukung media : audio, video, dan berbagai format gambar (MPEG4, H.264, MP3, AAC, AMR, JPG, PNG, GIF)

5. GSM, Bluetooth, EDGE, 3G, and Wifi.

6. Camera, Global Positioning System (GPS), compass dan accelerometer.

7. Lingkungan pengembangan yang komplek, termasuk emulator, peralatan debugging, dan plugin untuk Eclipse IDE.[10]

Mobile aplikasi yang dapat digunakan walaupun pengguna berpindah dengan mudah dari satu tempat ke tempat yang lain tanpa terjadi pemutusan atau terputusnya komunikasi.[11] 


\section{4) Data Base}

MySQL adalah sebuah perangkat lunak sistem manajemen basis data SQL atau yang dikenal dengan DBMS (database management system), database ini multithread, multi-user. MySQL tersedia sebagai perangkat lunak gratis di bawah lisensi GNU General Public License (GPL), tetapi mereka jugamenjual dibawah lisensi komersial untuk kasus-kasus yang bersifat khusus.[12] . Untuk mengakses MYSQL, dapat menggunakan Aplikasi Browser dengan mengakses alamat http://localhost/phpmyadmin/.[13]

\section{ANALISIS DAN PERANCANGAN}

Kontrol aktif dan non aktif alarm berada pada smartphone android yang berguna untuk menyalakan dan mematikan alarm sirine sebagai upaya pencegahan terhadap kemungkinan tindak kejahatan. Metode perancangan sistem digambarkan dalam deskripsi umum sistem kamera pengawas sebagai berikut. [14]

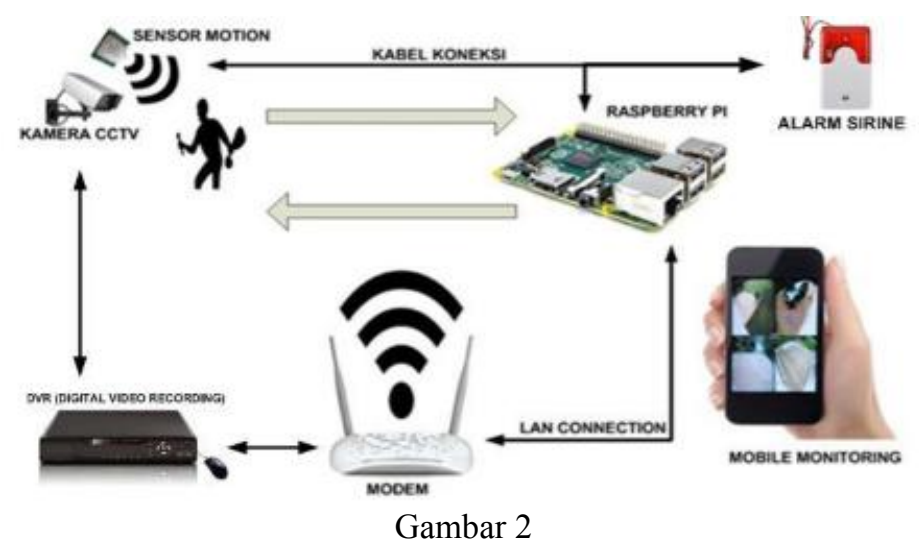

Berikut flowchart sistem secara keseluruhan yang dikembangkan:

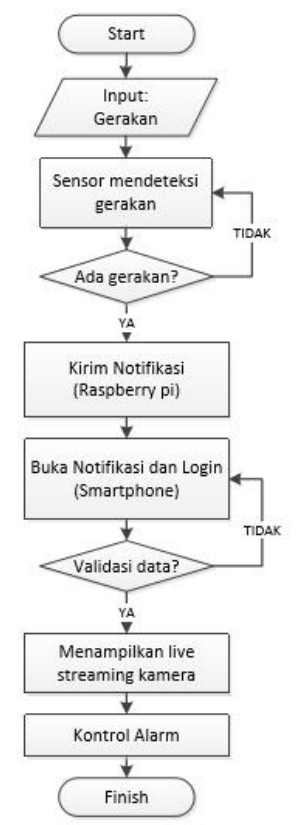

Awalnya pengguna mengaktifkan sensor gerak pada sistem kamera pengawas. Apabila sensor gerak menerima sinyal gerakan, maka sinyal gerakan tersebut akan dikirimkan ke microcontroller raspberry pi, raspberry pi memproses sinyal gerakan tersebut dengan mengirimkan pemberitahuan atau notifikasi pada perangkat bergerak milik pengguna (smartphone android). Pengguna membuka notifikasi dan login pada smartphone android dengan mengisi data berupa user, password dan alamat ip camera untuk dapat terhubung ke sistem. Selanjutnya aplikasi akan memeriksa apakah data yang diisikan oleh pengguna benar atau salah. Jika benar pengguna akan dapat mengakses kamera dan mendapatkan streaming dari kamera CCTV tersebut, jika salah maka aplikasi akan menampilkan pesan kesalahan dan meminta pengguna untuk melakukan pengisian data ulang. Terakhir pengguna dapat memutuskan kendali kontrol alarm untuk pesan peringatan.[14] Perancangan penempatan kamera 
CCTV dipasang diatas dan atau mendekati pintu masuk sehingga para pengunjung ruangan yang hendak masuk dapat di identifikasi wajah pengguna dengan identitas yang sedang dipakai.[15]

\section{KESIMPULAN}

1) Mikrokontroler ATMega 16 dapat digunakan untuk melakukan komunikasi serial dan penggerak relayboard.[2]

2) Evaluasi sistem berjalan dilakukan untuk mengetahui kapasitas dari sistem yang akan ditambahkan beban.[1]

3) Tampilan pada layar Android Mini PC MK809 II sesuai dengan rancangan.[5]

4) Aplikasi dapat melakukan pemantauan live streaming dengan format Motion-JPEG melalui kamera IP dengan perangkat mobile menggunakan platform Android.[12]

\section{References}

[1] M. Atmega, E. Yuliza, dan T. U. Kalsum, “Alat Keamanan Pintu Brankas Berbasis Sensor Sidik Jari Dan Passoword Digital Dengan Menggunakan,” vol. 11, no. 1, hal. 1-10, 2015.

[2] M. Saleh, F. T. Pontia, J. T. Elektro, F. Teknik, dan U. Tanjungpura, "Rancang Bangun Sistem Monitoring Keamanan Lingkungan Berbasis Wifi Menggunakan Ip Camera," vol. 2, hal. 2-5.

[3] R. Wirelless et al., "Perancangan Teknologi IP Camera di Jaringan Radio Wirelless PT. PLN Wilayah Suluttenggo," EJournal Tek. Elektro Dan Komput., vol. 1, no. 3, hal. 1-7, 2012.

[4] A. Darmawan, D. Yuliawati, O. Marcella, dan R. Firmandala, "Sistem Absensi dan Pelaporan Berbasis Fingerprint dan SMS Gateway,” Explor. J. Sist. Inf. dan Telemat., vol. 7, no. 1, 2016.

[5] L. S. Kristin, "Pengaruh Penerapan Presensi Sidik Jari ( Fingerprint ) terhadap Kinerja Guru Melalui Motivasi Kerja di SMA Negeri 5 Malang," Sist. Inf., hal. 170-177, 2016.

[6] M. D. Ayatullah, E. A. Sandi, dan G. H. Wibowo, "Rancang Bangun Absensi Mahasiswa Berbasis Fingerprint Menggunakan Komunikasi Wireless," vol. 04, no. 02, hal. 152-158, 2019.

[7] M. A. Gandhi, "Penerapan Absensi Finger Print Dalam Mendisiplinkan Kerja Pegawai Di Sekolah Menengah Kejurujan (Smk) Sekolah Menengah Tekhnik Industri (Smti) Bandar Lampung,” 2017.

[8] M. Azam dan A. I. Fibriana, "Sistem Informasi Admisi Pasien Membantu Ketepatan Pengambilan Keputusan Admisi Pasien," Kesmas Natl. Public Heal. J., vol. 6, no. 2, hal. 51, Okt 2011.

[9] F. Kurnia, "Implementasi Sistem Penyimpanan Terpusat Menggunakan Pydio 8 . 0 Community pada Universitas Islam Batik Surakarta," J. Emit., vol. 16, no. 02, 2014.

[10] D. Ashardi, "rancang bangun aplikasi pemantau ruangan melalui kamera Ip menggunakan platrform android," Sist. Dan Teknol. Inf., hal. 56-61, 2013.

[11] M. Bestari, "Rancangan Aplikasi Monitoring Kamera Cctv Untuk Perang' Kat Mobile Berbasis Android," Teknol. Inform. dan Komput., vol. 3, hal. 46, 2016.

[12] R. Juwitra Apsari, "Monitoring Keamanan Rumah Dengan Menggunakan Mikrokontroler Melalui Web," J. Manaj. Inform., vol. 8, no. 1, hal. 87-95, 2017.

[13] "Sistem Keamanan Database Berbasis Restfull Pada Content Management System Wordpress ( Studi Kasus : STIKI Malang )," no. January, 2019.

[14] D. E. Kurniawan dan S. Fani, "Perancangan sistem kamera pengawas berbasis perangkat bergerak menggunakan raspberry pi," J. Ilm. Teknol. Inf. Terap., vol. III, no. 2, hal. 140-146, 2017.

[15] Sutoyo, Triyono, dan Saepudin, "Penerapan Fitur Kamera CCTV Untuk Access Control System ( ACS ) Menggunakan System Onguard 2013,” Semin. Naional Informasi, Komun. dan Ind., hal. 400-407, 2017. 